\title{
Macular Edema
}

National Cancer Institute

\section{Source}

National Cancer Institute. Macular Edema. NCI Thesaurus. Code C35468.

Accumulation of intraretinal fluid and protein in the macula, which may result in swelling and decreased central vision. 